\title{
Impacts of Grain-for-Green and Grain-for-Blue Policies on Valued Ecosystem Services in Shandong Province, China
}

\author{
Wei Song, ${ }^{1}$ Xiangzheng Deng, ${ }^{1,2}$ Bing Liu, ${ }^{3}$ Zhaohua $\mathrm{Li},{ }^{4}$ and Gui Jin ${ }^{4}$ \\ ${ }^{1}$ Key Laboratory of Land Surface Pattern and Simulation, Institute of Geographic Sciences and Natural Resources Research, \\ Chinese Academy of Sciences, Beijing 100101, China \\ ${ }^{2}$ Center for Chinese Agricultural Policy, Chinese Academy of Sciences, Beijing 100101, China \\ ${ }^{3}$ College of Geomatics, Shandong University of Science and Technology, Qingdao, Shandong 266590, China \\ ${ }^{4}$ Resources and Environmental Science, Hubei University, Wuhan, Hubei 430062, China
}

Correspondence should be addressed to Xiangzheng Deng; dengxz.ccap@gmail.com

Received 13 September 2014; Accepted 20 December 2014

Academic Editor: Jinwei Dong

Copyright (C) 2015 Wei Song et al. This is an open access article distributed under the Creative Commons Attribution License, which permits unrestricted use, distribution, and reproduction in any medium, provided the original work is properly cited.

China launched a series of ecological restoration policies to mitigate its severe environmental challenges in the late 1990s. From the beginning, the effects and influences of the ecological restoration policies have been hotly debated. In the present study, we assessed the effects of two vital ecological restoration policies (Grain-for-Green and Grain-for-Blue) on valued ecosystem services in Shandong province. A new method based on the net primary productivity and soil erosion was developed to assess the ecosystem service value. In the areas implementing the Grain-for-Green and Grain-for-Blue policies, the ecosystem service value increased by $24.01 \%$ and $43.10 \%$ during 2000-2008, respectively. However, comparing to the average increase of ecosystem service value (46.00\%) in the whole of Shandong province in the same period, Grain-for-Green and Grain-for-Blue did not significantly improve overall ecosystem services. The ecological restoration policy led to significant tradeoffs in ecosystem services. Grain-for-Green improved the ecosystem service function of nutrient cycling, organic material provision, and regulation of gases but decreased that of water conservation. Grain-for-Blue increased the water conservation function but led to a reduction in the function of soil conservation and nutrient cycling.

\section{Introduction}

Over the past 50 years, $60 \%$ of worldwide ecosystem services have degraded due to social and economic development [1]. In China, ecological degradation is also extensive; for example, $23 \%$ of the area in China has suffered ecological degradation [2]. The economic loss from ecological degradation accounted for over $13 \%$ of the national gross domestic product [3]. Awakening to the severe effects of ecological degradation, the Chinese government implemented two ecological restoration policies at the end of the 1990s, that is, the Grain-for-Green policy and Grain-for-Blue policy.

The Grain-for-Green policy, the largest land retirement/afforestation program in China, was launched in 1999 to mitigate land degradation (soil erosion) by returning steeply sloping cultivated land to forest area or grassland [2, 4-7]. The Grain-for-Blue policy was launched in 1998, aiming to return cultivated land to water areas, that is, relinquishing the cultivated land at the periphery of water areas [8-11].

Policy can affect decision making and change the ways people utilize and manage ecosystems [12]. Evaluating the consequences of a policy is a critical lesson from the Millennium Ecosystem Assessment [13]. In recent years, the policy research interest in ecosystems has focused on the policy tools [14,15], policy impacts [16-18], policy incentives [19], policy option [20], policy assessment approach [21], and policy making $[22,23]$. For example, Brady et al. [24] modeled the impacts of agricultural policy on ecosystem services using an agent-based approach; Bronner et al. [25] assessed the impacts of US stream compensatory mitigation policy on ecosystem functions and services; Geneletti [26] assessed the impacts of alternative land use zoning policies on future ecosystem services; Simpson [27] estimated the effects of conservation policy on ecosystems. 
As an effective approach to recognize the multiple benefits provided by ecosystems, the work of economic valuation of ecosystem services has been widely conducted since $1990[28,29]$. These works cover the method developed in valuating ecosystem services and the estimation of ecosystem service value in different regions and ecosystems. One of the most notable assessments of ecosystem service value (ESV) was conducted by Costanza et al. [30, 31], who estimated 17 ESV provided by 16 dominant global biomes using a market valuation method. Other researchers also estimated ESV of tropical forests [32-36] and protected areas [37$39]$, endangered species management $[40,41]$, and different biological resources [28, 42-44].

Although Grain-for-Green and Grain-for-Blue have been implemented over 10 years in China, few works have been conducted to assess the ecological impacts of the two ecological restoration policies particularly from the perspective of changes in ESV. In this paper, we evaluated the effects of Grain-for-Green and Grain-for-Blue on ESV by a newly developed approach. Specifically, the aims of this paper are to (a) examine land use change in Shandong province during 2000-2008, (b) assess the changes in ESV, and (c) estimate the effects of Grain-for-Green and Grain-for-Blue on ESV.

\section{Study Area and Data Sources}

2.1. Study Area. Shandong province, located on the eastern edge of the North China Plain $\left(114^{\circ} 19^{\prime}-122^{\circ} 43^{\prime} \mathrm{E}, 34^{\circ} 22^{\prime}-\right.$ $38^{\circ} 15^{\prime} \mathrm{N}$ ) and the lower reaches of the Yellow River, is a coastal province in China (Figure 1). It covers a total area of over $151,100 \mathrm{~km}^{2}$ with plains terrain accounting for 55\%, mountainous area for $15.5 \%$, and hilly area for $13.2 \%$ (Figure 1). The northwest, west, and southwest of the Shandong are all part of the North China Plain. The central region of the province is mountainous, with Mount Tai being the most prominent. Shandong province lies in the warm-temperate zone with a continental monsoon climate.

2.2. Data Sources. The land use maps of Shandong province in 2000 and 2008 were obtained from the Institute of Geographic Sciences and Natural Resources Research of the Chinese Academy of Sciences [45]. The maps were interpreted from Landsat TM (Thematic Mapper) satellite images by the human-machine interactive approach. The average accuracy of the maps is over 95\% [46]. The land use was divided into six primary types and 25 subclasses $[47,48]$.

The net primary productivity (NPP) data in Shandong are the products of EOS/MODIS of NASA. The Normalized Difference Vegetation Index (NDVI) data are sourced from SPOT-vegetation with a temporal step of 10 days. The data formats of NPP and NDVI are all $1 \mathrm{~km}$ grid. Precipitation and temperature in Shandong province were gained from the China Meteorological Data Sharing Service System (http://cdc.cma.gov.cn/home.do) and interpolated in spatial. The soil nutrients data such as the contents of $\mathrm{N}, \mathrm{P}, \mathrm{K}$, and organic matter were taken from the soil map generated from the second soil survey of China. The actual evapotranspiration data, which were calculated by IBIS model with a temporal step of 8 days, were sourced from the China Data Sharing Infrastructure of Earth Systems Science.

\section{Method}

3.1. Value Quantification of Ecosystem Services. The method for assessing ESV can be summarized into two categories, that is, the primary data based method and proxy based method [49]. The primary data based method directly assesses the ESV according to the primary data from the study area. For the complicated calculation process, many models have been developed to assess ESV, for example, InVEST, ARIES, SoLVES, and MIMES. The proxy based method assesses ESV by assigning each biome a value. One of the most representative proxy based methods was developed by Costanza et al. [31]. The merit of the primary data based method is high accuracy while the demerit is the complexity. Since running ESV models usually needs numerous parameters, the primary data based method is usually not convenient. The merit of the proxy based method is the convenience while the accuracy of this method is usually challenged.

In this paper, we developed a novel method to assess ESV. The method is one of the primary data based methods. However, since the calculation of ESV in this method is based on remote sensing data such as NPP, the calculation process is very convenient. Considering data accessibility and technique feasibility, we estimated five kinds of ESV, that is, values for provision of organic material, nutrient cycling, soil conservation, water conservation, and regulation of gases.

3.2. Assessment of the Value of Provision of Organic Material. The value of organic material of an ecosystem was assessed by NPP. The equation is as follows:

$$
\begin{gathered}
V_{\mathrm{om}}=\sum \mathrm{NPP}(x) \times P_{\mathrm{om}}, \\
P_{\mathrm{om}}=\operatorname{NPP}(x) \times 2.2 \times 0.67 \times P_{\mathrm{sc}},
\end{gathered}
$$

where $V_{\text {om }}$ is the value of provision of organic material; $\operatorname{NPP}(x)$ is the organic material produced in $x$ pixel; $P_{\mathrm{sc}}$ is the price of standard coal in 2000.

3.3. Assessment of the Value of Nutrient Cycling. We utilized the saved inputs due to nutrient cycling in agricultural production to assess the value of nutrient cycling. The formula is as follows:

$$
V_{\mathrm{nc}}=\sum V_{\mathrm{nc}_{i}}(x)=\sum \operatorname{NPP}(x) \times R_{i 1} \times R_{i 2} \times P_{i},
$$

where $V_{\mathrm{nc}}$ is the value of nutrient cycling in an ecosystem; $i$ is the nutrient elements of $\mathrm{N}$ (nitrogen), $\mathrm{P}$ (phosphorus), or $\mathrm{K}$ (potassium); $\mathrm{NPP}(x)$ is the organic material produced in $x$ pixel; $V_{\mathrm{nc}_{i}}(x)$ is the accumulated value of $\mathrm{N}, \mathrm{P}$, and $\mathrm{K} ; R_{i 1}$ is the distribution rate of nutrient elements of $\mathrm{N}$, $\mathrm{P}$, and $\mathrm{K}$ in organic material in different ecosystems; $R_{i 2}$ is the converted coefficients of $\mathrm{N}, \mathrm{P}$, and $\mathrm{K}$ to corresponding chemical fertilizer; $P_{i}$ is the chemical fertilizer price of $\mathrm{N}, \mathrm{P}$, and $\mathrm{K}$ in 2000. 


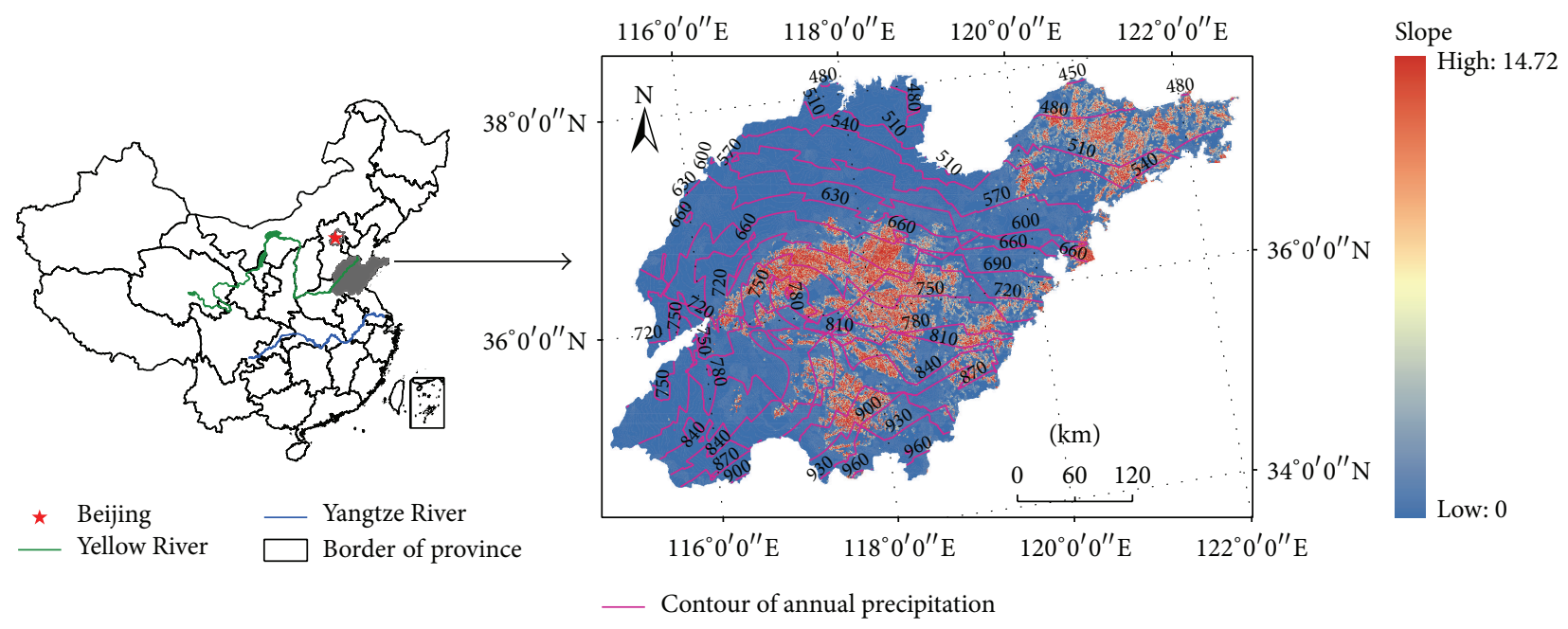

FIGURE 1: Slope and precipitation of Shandong province, China.

3.4. Assessment of the Value of Water Conservation. The function of water conservation of an ecosystem is similar to that of a reservoir. Therefore, we utilized the average construction cost of a reservoir to assess the value of water conservation. The formula is as follows:

$$
V_{\mathrm{wc}}=\sum V(x) \times P_{w}
$$

where $V_{\text {wc }}$ is the value of water conservation; $V(x)$ is the water conservation amount in $x$ pixel; $P_{w}$ is the average cost of reservoir construction in 2000.

According to the difference in underlying surface, we utilized two different approaches to assess the water conservation amount of an ecosystem. When the underlying surface is soil, the equation is as follows:

$$
V_{s}(x)=\sum P_{\text {mean }}(x) \times K_{w} \times R_{w},
$$

where $V_{s}(x)$ is the annual water conservation amount in $x$ pixel; $P_{\text {mean }}(x)$ is the monthly precipitation in $x$ pixel; $K_{w}$ is the ratio of runoff generated from precipitation. $R_{w}$ is the coefficient of reducing runoff by comparison with bare land without vegetation. $R_{w}$ of cultivated land, woodland, and grassland are valued as $0.4,0.29$, and 0.24 , respectively, while $R_{w}$ of other land use types are valued as 0 [50].

When the underlying surface of an ecosystem is an area of water, the equation is as follows:

$$
V_{\mathrm{wc}}(x)=\sum\left(P_{\text {mean }}(x)-E T_{a}(x)\right),
$$

where $V_{\mathrm{wc}}(x)$ is the annual water conservation amount in $x$ pixel; $P_{\text {mean }}(x)$ is the monthly precipitation in $x$ pixel; $E T_{a}(x)$ is the monthly actual evaporation in $x$ pixel.

3.5. Assessment of the Value of Soil Conservation. Soil erosion usually leads to three different kinds of value loss in an ecosystem, that is, a reduction in soil fertility, river channel sedimentation, and loss of top soil. Therefore, the assessment of the value of soil conservation is composed of three sections:

$$
V_{a c}=V_{e f}+V_{e n}+V_{e s}
$$

where $V_{a c}$ is the value of soil conservation; $V_{e f}$ is the value of soil fertility conservation; $V_{e n}$ is the value of reducing soil sedimentation in a river channel; $V_{e s}$ is the value of the loss of top soil.

3.5.1. Assessment of the Soil Conservation Amount. The soil erosion amount without any vegetation is viewed as the potential soil erosion amount. The soil erosion amount that actually occurred is looked on as the actual soil erosion amount. The difference between the amount of potential soil erosion and actual erosion is the soil conservation amount. The soil erosion was assessed by Universal Soil Loss Equation:

$$
\begin{aligned}
& A_{p}=R \times K \times L \times S, \\
& A_{v}=R \times K \times L \times S \times C \times P, \\
& A_{c}=A_{p}-A_{v},
\end{aligned}
$$

where $A_{p}$ is the amount of potential soil erosion; $A_{v}$ is the amount of actual soil erosion; $A_{c}$ is the soil conservation amount; $K$ is the soil erodible factor; $L$ is the slope length; $S$ is the slope factor; $C$ is the vegetation and crop management factor; $P$ is the soil conservation measure factor. Detailed parameters of $R, K, L, S, C$, and $P$ were referenced from Wischmeier [51], Renard et al. [52], Flanagan et al. [53], Kuok et al. [54], and Renard and Foster [55].

3.5.2. Assessment of the Value of Soil Fertility Conservation. $\mathrm{N}, \mathrm{P}$, and $\mathrm{K}$ are the three most important nutrients in soil. Soil erosion could lead to the nutrients' losses and a decrease in soil fertility. Thus, we estimated the value of soil fertility 
conservation by assessing the nutrient element value of the soil conservation amount. The equation is as follows:

$$
V_{e f}=\sum A_{c}(x) \times C_{i} \times P_{i}
$$

where $V_{e f}$ is the value of soil fertility conservation; $A_{c}(x)$ is the soil conservation amount in $x$ pixel; $C_{i}$ is the price of $\mathrm{N}$, $\mathrm{P}$, and $\mathrm{K}$ fertilizer in 2000.

3.5.3. Assessment of the Value of the Loss of Top Soil. The value of the loss of top soil was assessed by calculating the value of conserved land where soil erosion has been avoided due to the protection of vegetation coverage in an ecosystem. The formula is as follows:

$$
V_{e s}=\frac{\sum A_{c}(x) \times P_{f}}{D_{\text {soil }} \times T_{\text {soil }}},
$$

where $V_{e s}$ is the value of the loss of top soil; $A_{c}(x)$ is the soil conservation amount in $x$ pixel; $D_{\text {soil }}$ is the soil density; $P_{f}$ is the economic benefits of forest planting which is valued as $26,400 \mathrm{CNY} / \mathrm{km}^{2}$.Year; $T_{\text {soil }}$ is the average soil thickness.

3.5.4. Assessment of the Value of Reducing Soil Sedimentation in a River Channel. In China, about $24 \%$ of sediments from soil erosion are deposited in reservoirs, lakes, and rivers according to the research of Ouyang et al. [56]. Thus, the value of reducing soil sedimentation in a river channel was assessed as follows:

$$
V_{e n}=\frac{\sum A_{c}(x) \times 0.24 \times P_{w}}{D_{\text {soil }}}
$$

where $V_{e n}$ is the value of reducing the soil sedimentation in a river channel; $P_{w}$ is the construction cost of a reservoir per unit; $A_{c}(x)$ is the quantity of soil conserved; $D_{\text {soil }}$ is the soil density.

3.6. Assessment of the Value of Regulation of Gases. The value of regulation of gases was assessed on the basis of the functions of $\mathrm{CO}_{2}$ absorption and $\mathrm{O}_{2}$ generation. The equation is as follows:

$$
V_{g r}=\sum 1.62 \times \mathrm{NPP}(x) \times P_{\mathrm{CO}_{2}}+\sum 1.2 \times \mathrm{NPP}(x) \times P_{\mathrm{O}_{2}},
$$

where $V_{g r}$ is the value of regulation of gases $\operatorname{NPP}(x)$ is the organic material in $x$ pixel; according to the photosynthesis and breathing reaction equation, it can be deduced that producing $1 \mathrm{~g}$ dry matter absorbs $1.62 \mathrm{~g} \mathrm{CO}_{2}$ and releases $1.2 \mathrm{~g}$ $\mathrm{O}_{2} ; P_{\mathrm{CO}_{2}}$ is the price of carbon tax, valued as $7.39 \times 10^{-4}$ $\mathrm{CNY} / \mathrm{g} \mathrm{C} ; P_{\mathrm{O}_{2}}$ is the price of producing $\mathrm{O}_{2}$, valued as $8.8 \times$ $10^{-4} \mathrm{CNY} / \mathrm{g} \mathrm{C}$.

\section{Results}

4.1. Changes in Land Use. In 2000, cultivated land in Shandong province comprised $67.62 \%$ of the total area, followed by built-up areas (12.62\%), grassland $(8.72 \%)$, forestry area $(6.44 \%)$, water area (3.44\%), and unused land (1.17\%).

Shandong province experienced drastic land use changes during 2000-2008. The features of land use change in Shandong were the expansion of built-up areas, reclamation of unused land, and drastic conversions in water areas. Due to rapid urbanization, urban built-up areas expanded by $56.13 \%$, with the built-up area increasing from 301,939 ha to 471,418 ha. However, unused land shrank by $16.54 \%$ due to reclamation (Figure 2). Both drastic increase and decrease occurred in the water areas. For example, reservoirs/ponds and streams/rivers significantly increased by $42.30 \%$ and $5.67 \%$, respectively, while beach and shore, lakes, and bottomland decreased by $53.46 \%, 23.66 \%$, and $21.99 \%$, respectively.

During 2000-2008, the conversion from cultivated land to built-up area reached 235,256 ha, contributing to $45.00 \%$ of the total conversions, followed by the conversion from cultivated land to water areas $(42,236 \mathrm{ha})$ and from grassland to cultivated land areas $(33,112 \mathrm{ha})$.

4.2. Changes in Value of Ecosystem Services. The ESV of Shandong was as high as 267.53 billion CNY in 2000. The value of regulation of gases contributed to $38.69 \%$ of the total ESV, followed by the values of soil conservation (34.83\%), water conservation (16.69\%), nutrient cycling (5.05\%), and organic material provision (4.73\%). The ESV per unit in Shandong ranged from 0 to $71.07 \mathrm{CNY} / \mathrm{m}^{2}$, with an average value of $1.76 \mathrm{CNY} / \mathrm{m}^{2}$ (Figure 3 ). The value of organic material provision per unit ranged from 0 to $0.37 \mathrm{CNY} / \mathrm{m}^{2}$ while the values of regulating gases, nutrient cycling, and soil conservation ranged from 0 to $2.90 \mathrm{CNY} / \mathrm{m}^{2}$, from 0 to $0.52 \mathrm{CNY} / \mathrm{m}^{2}$, and from 0 to $69.36 \mathrm{CNY} / \mathrm{m}^{2}$, respectively. The average values of regulating gases, organic material provision, water conservation, nutrient cycling, and soil conservation are $0.68 \mathrm{CNY} / \mathrm{m}^{2}, 0.08 \mathrm{CNY} / \mathrm{m}^{2}, 0.29 \mathrm{CNY} / \mathrm{m}^{2}$, $0.09 \mathrm{CNY} / \mathrm{m}^{2}$, and $0.61 \mathrm{CNY} / \mathrm{m}^{2}$, respectively in 2000 .

In spatial, total ESV is high in central and eastern Shandong while low in northern and western Shandong (Figure 3). The spatial feature of soil conservation value is similar to that of total ESV. The spatial distribution of organic material provision value, gases regulating value, and nutrient cycling value all gradually decreased from the northeast to the southwest. However, the value of water conservation gradually decreased from the southwest to the northeast.

In 2008, the ESV of Shandong province reached 390.59 billion CNY, with an increase of $46.00 \%$ compared to 2000 . The soil conservation value increased by 71.64 billion CNY contributing to $58.21 \%$ of the total increase. Values of regulating gases, water conservation, nutrient cycling, and organic material provision increased by 37.40 billion CNY, 4.23 billion CNY, 5.00 billion CNY, and 4.80 billion CNY, respectively, contributing $30.39 \%, 3.44 \%, 4.06 \%$, and $3.90 \%$ of the total increase, respectively. In 2008, the average ESV per unit of regulating of gases, water conservation, soil conservation, nutrient cycling, and organic material provision reached $0.93 \mathrm{CNY} / \mathrm{m}^{2}, \quad 0.32 \mathrm{CNY} / \mathrm{m}^{2}, \quad 1.09 \mathrm{CNY} / \mathrm{m}^{2}, 0.12 \mathrm{CNY} / \mathrm{m}^{2}$, and $0.12 \mathrm{CNY} / \mathrm{m}^{2}$, respectively. The total average ESV per unit is $2.58 \mathrm{CNY} / \mathrm{m}^{2}$. 

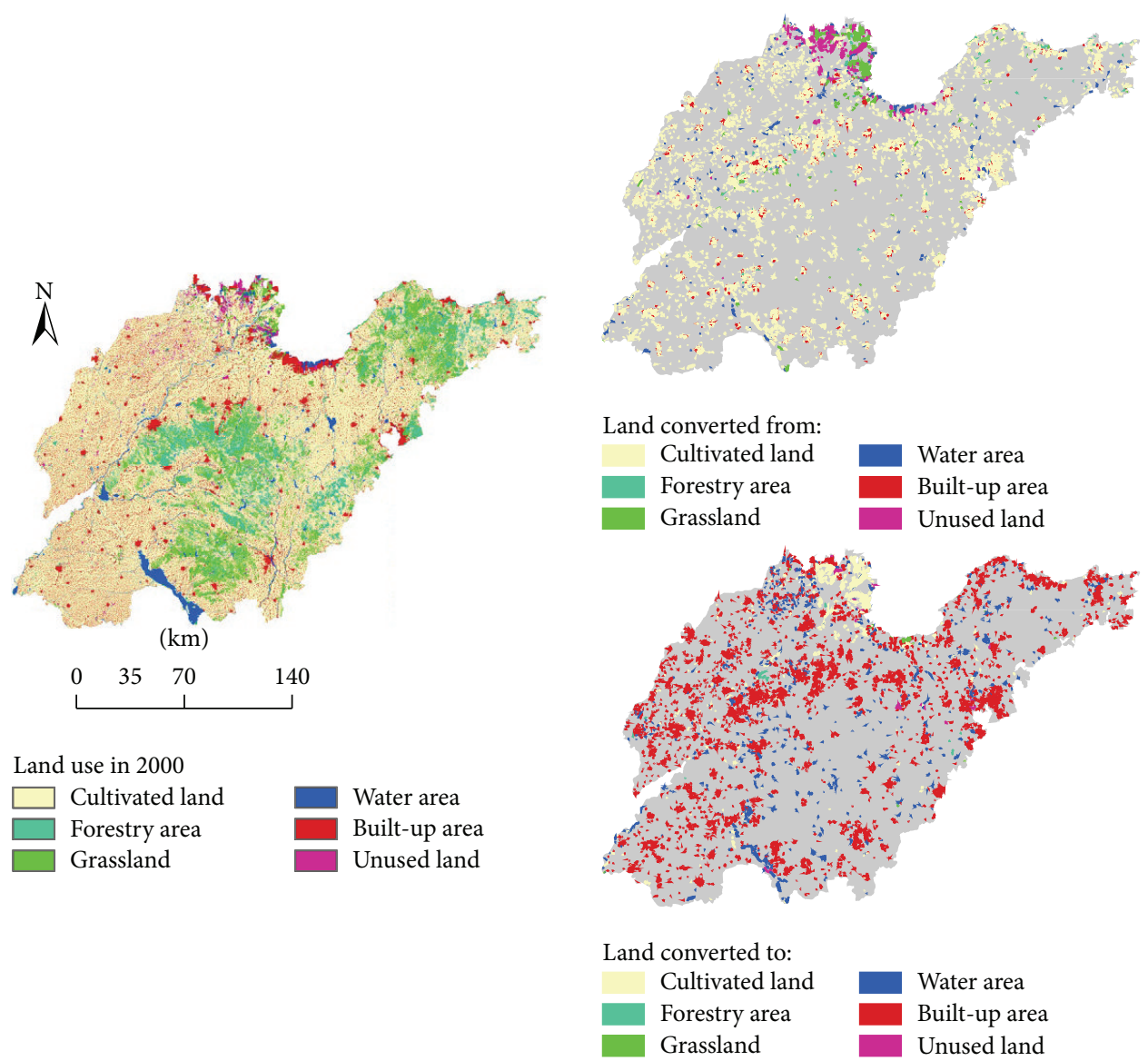

FIGURE 2: Land use changes in Shandong province during 2000-2008.

In spatial, total ESV and value of soil conservation significantly increased in central and eastern Shandong province. In these areas, mountains (Figure 4) are the dominant topography. The changes in value of organic material provision, regulating gases, and nutrient cycling all significantly increased in eastern Shandong while decreased in the coastal zone of Shandong. Water conservation value significantly increased in water areas.

4.3. Changes in Value of Ecosystem Services in Response to Land Use. One of the most important consequences of land use change is land use conversion. During 2000-2008, $40.57 \times 10^{4}$ ha of land in total in Shandong experienced conversions. The ESV of these converted lands in 2000 was 3.78 billion CNY while that in 2008 was 3.81 billion CNY, showing an increase of $0.74 \%$ (Figure 5 ).

However, conversions from other land use types to builtup areas significantly decreased the ESV in Shandong. The conversion from cultivated land to built-up areas reduced the ESV by 54.75 million CNY, contributing $89.49 \%$ of the ESV loss from land use conversion. Conversion from water areas, forestry areas, grassland, and unused to built-up areas increased by $2418.54 \times 10^{4} \mathrm{CNY}, 1322.89 \times 10^{4} \mathrm{CNY}, 1283.96$ $\times 10^{4} \mathrm{CNY}$, and $932.15 \times 10^{4} \mathrm{CNY}$, respectively (Figure 5). The conversion from water areas to unused land also led to a decrease of $469.42 \times 10^{4} \mathrm{CNY}$. Other kinds of land use conversion do not lead to a decrease in ESV.

4.4. Impacts of Ecological Restoration on Ecosystem Services. The vital consequences of the two ecological restoration policies on land use are the conversions from cultivated land to forestry area/grassland and to water areas. Theoretically, if the sites implementing the two ecological restoration policies in spatial are known, changes in ESV in these areas during 2000-2008 could be viewed as the effects of the two ecological restoration policies. However, information is lacking on the location and the degree of implementation for the two ecological restoration policies in Shandong. It should be noted that the starting time of our research was 2000 when the two ecological restoration policies had just been launched. Furthermore, during 2000-2008, no other policies were implemented to drive the conversion from cultivated land to grassland, forestry area, or water areas. Most of the conservations from cultivated land to grassland/forestry area or water area during 2000-2008 could be similarly looked upon as the consequence of the Grain-for-Green and Grainfor-Blue policies.

Accordingly, we assessed the impacts of Grain-for-Green and Grain-for-Blue on changes in ESV. Grain-for-Green in total added an ESV of $5.19 \times 10^{6} \mathrm{CNY}$, while Grain-for-Blue 

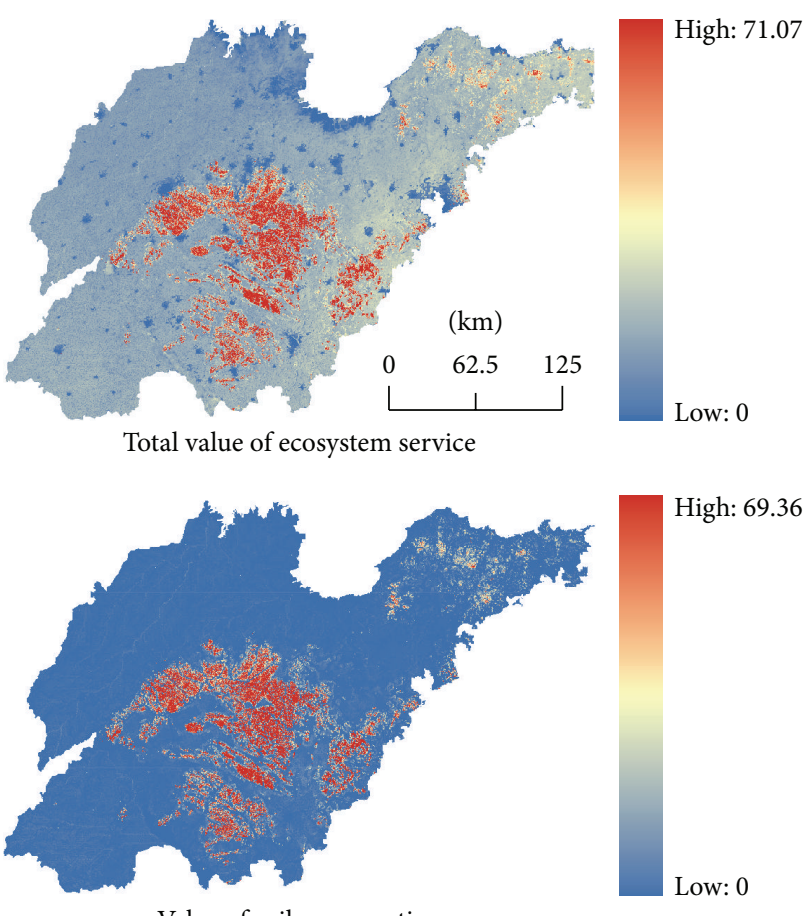

Value of soil conservation

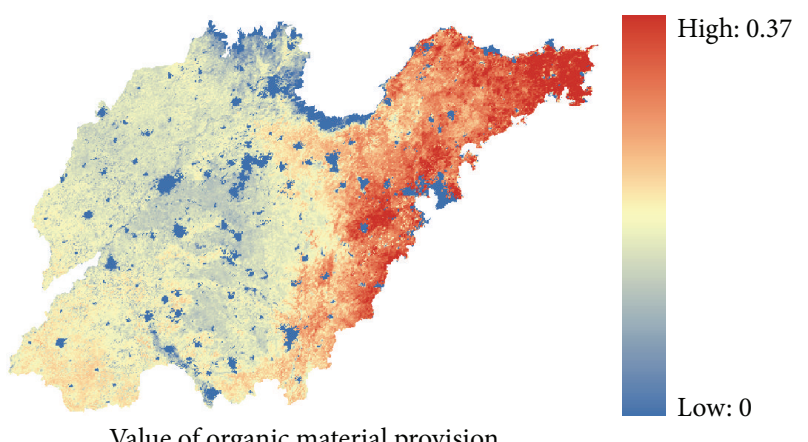

$\left(\mathrm{CNY} / \mathrm{m}^{2}\right)$
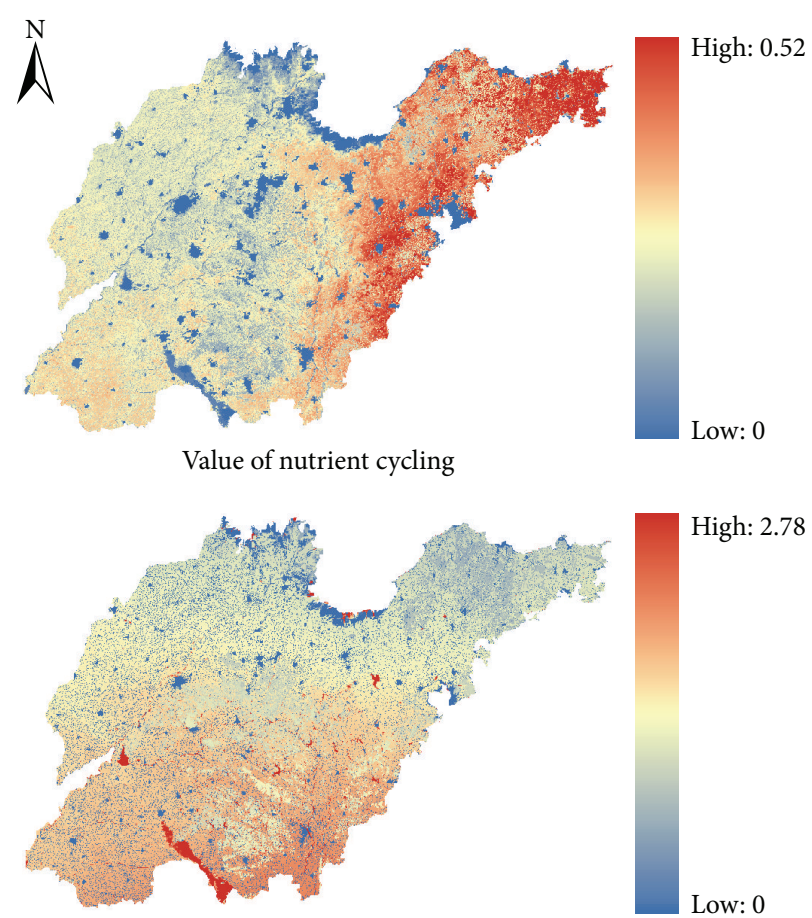

Value of water conservation
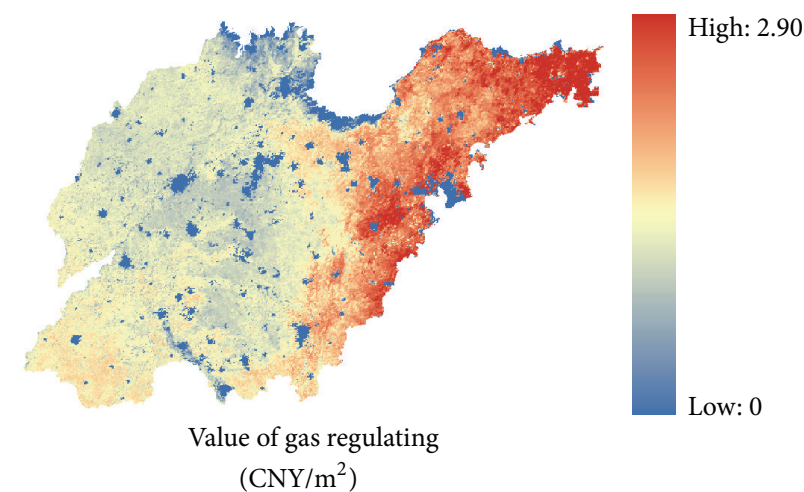

$\left(\mathrm{CNY} / \mathrm{m}^{2}\right)$

Figure 3: Value of ecosystem services in Shandong in 2000.

led to an increase of ESV of $206.77 \times 10^{6} \mathrm{CNY}$ (Table 1). The two ecological restoration policies in total led to an increase of $42.30 \%$ in ESV. The ESV per unit increased from $1.23 \mathrm{CNY} / \mathrm{m}^{2}$ in 2000 to $1.53 \mathrm{CNY} / \mathrm{m}^{2}$ in 2008 due to the implementation of Grain-for-Green. The ESV per unit increased from $1.14 \mathrm{CNY} / \mathrm{m}^{2}$ in 2000 to $1.63 \mathrm{CNY} / \mathrm{m}^{2}$ in 2008 due to the implementation of Grain-for-Blue. The effects of Grain-for-Blue on ecosystem services seem better than those of Grain-for-Green.

The two ecological restoration policies produced different results for the ecosystem service value. For the Grain-forGreen policy, the value of nutrient cycling, regulating gases, organic material provision, and soil conservation increased by $64.12 \%, 38.98 \%, 40.00 \%$, and $18.25 \%$, respectively, while the value of water conservation decreased by $21.48 \%$ (Table 2). For the Grain-for-Blue policy, the value of water conservation significantly increased by $103.12 \%$, followed by the increase in regulating gases $(23.60 \%)$ and organic material provision (25.72\%). However, the values of soil conservation and nutrient cycling decreased by $100.00 \%$ and $56.20 \%$.

\section{Discussions and Conclusion}

The main objective of Grain-for-Green was to restore forests and grasslands in an effort to control soil erosion in China from 1998. In this paper, we found that the values of soil conservation increased by $18.25 \%$ due to Grain-for-Green during 2000-2008. However, the value of soil conservation in the whole of Shandong province increased by $76.87 \%$ during the same period. Grain-for-Green in Shandong does not significantly reduce soil erosion. The reason could be that Grain-for-Green in Shandong was mainly implemented in low sloping areas where soil erosion is not significant. The 


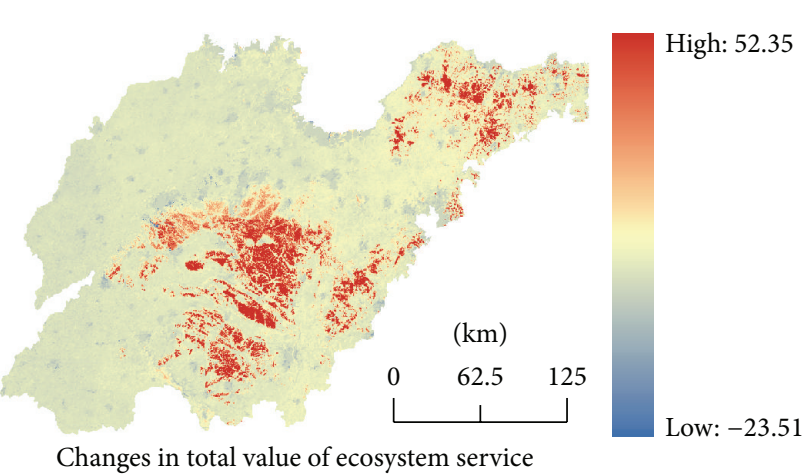

Changes in total value of ecosystem service

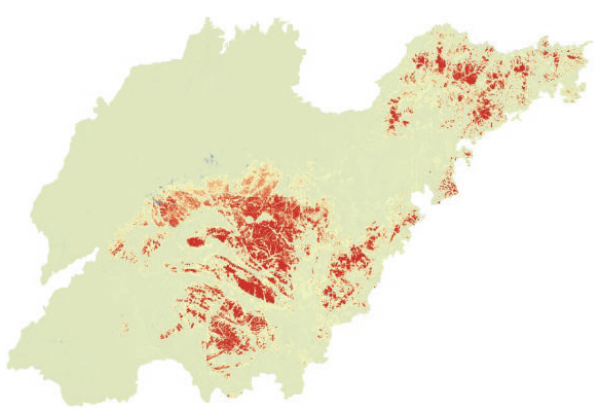

Changes in value of soil conservation

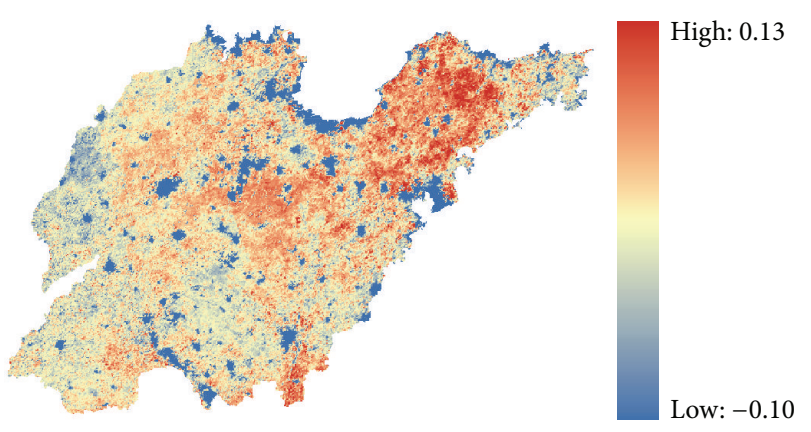

Changes in value of organic material provision $\left(\mathrm{CNY} / \mathrm{m}^{2}\right)$

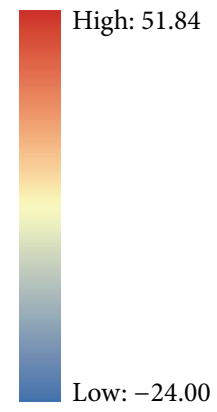

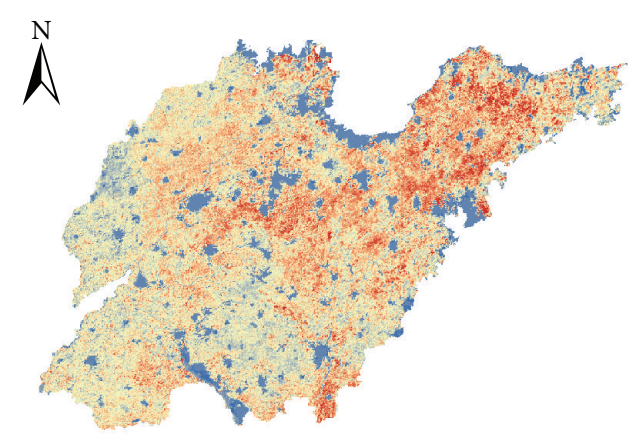

Changes in value of nutrient cycling

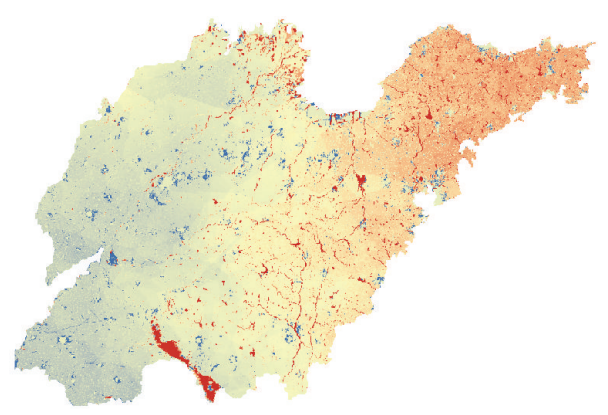

Changes in value of water conservation

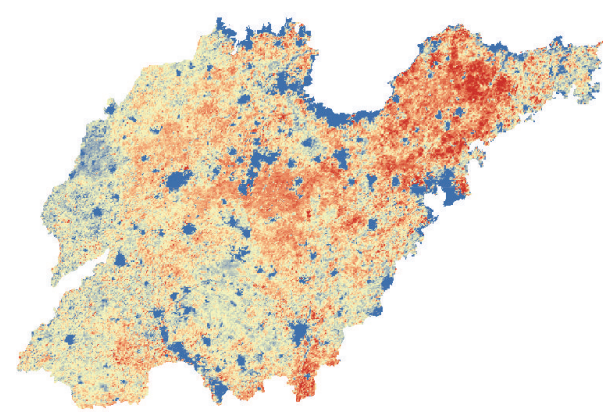

Changes in value of gas regulating $\left(\mathrm{CNY} / \mathrm{m}^{2}\right)$
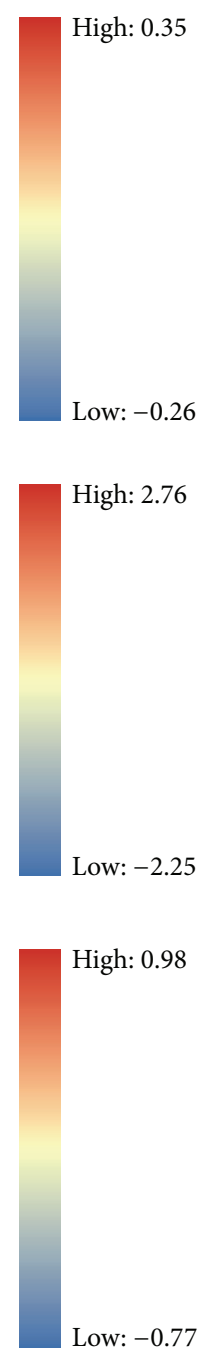

Low: -0.77

FIGURE 4: Changes in value of ecosystem services in Shandong during 2000-2008.

TABLE 1: Changes in ESV in response to ecological restoration policies.

\begin{tabular}{lccccccc}
\hline \multirow{2}{*}{ Policy } & \multicolumn{3}{c}{ Total value $\left(\times 10^{6} \mathrm{CNY}\right)$} & \multicolumn{3}{c}{ Value per unit $\left(\mathrm{CNY} / \mathrm{m}^{2}\right)$} & \multirow{2}{*}{ Change percentage $(\%)$} \\
& 2000 & 2008 & Change & 2000 & 2008 & Change & 24.30 \\
Grain-for-Green & 21.36 & 26.55 & 5.19 & 1.23 & 1.53 & 0.30 & 4.49 \\
Grain-for-Blue & 479.68 & 686.45 & 206.77 & 1.14 & 1.63 & 0.49 & $\mathbf{0 . 4 8}$ \\
Total & $\mathbf{5 0 1 . 0 4}$ & $\mathbf{7 1 3 . 0 0}$ & $\mathbf{2 1 1 . 9 6}$ & $\mathbf{1 . 1 4 1}$ & $\mathbf{1 . 6 2}$ & $\mathbf{4 2 . 3 0}$ \\
\hline
\end{tabular}

implementation of Grain-for-Green in these areas has limited positive effects on controlling soil erosion.

In comparison to the soil conservation value, Grainfor-Green did improve the ecosystem service function of nutrient cycling, organic material provision, and regulating gases. During 2000-2008, the values of nutrient cycling, organic material provision, and regulating gases increased by $64.12 \%, 40.00 \%$, and $38.98 \%$, respectively, in the areas implementing Grain-for-Green, but increased by $37.02 \%$, $37.90 \%$, and $36.13 \%$, respectively, in the whole of Shandong. The ESV of the areas implementing the Grain-for-Blue policy increased by $43.10 \%$ during $2000-2008$. The increase in water conservation value accounted for most of the added ESV. In the same period, the value of water conservation in the whole of Shandong increased by $16.69 \%$, while it increased by $103.12 \%$ in Grain-for-Blue areas. Grain-for-Blue significantly improved the ecosystem service function of water conservation due to the improvement of the water regulating function in water areas.

We assessed five kinds of ecosystem service values in Shandong province. The ecological restoration policies led to significant tradeoffs in ESV. Although Grain-for-Green 
TABLE 2: Changes in different ecosystem service values in response to ecological restoration policies.

\begin{tabular}{lcccc}
\hline Policy & Ecosystem service value & $2000\left(10^{4} \mathrm{CNY}\right)$ & $2008\left(10^{4}\right.$ CNY $)$ & Change percentage $(\%)$ \\
\hline & Regulating gases & 1169.29 & 1625.10 & 38.98 \\
& Water conservation & 554.92 & 435.71 & -21.48 \\
Grain-for-Green & Soil conservation & 101.31 & 119.80 & 18.25 \\
& Nutrient cycling & 166.66 & 273.53 & 64.12 \\
& Organic material provision & 143.36 & 200.71 & 40.00 \\
& Total & $\mathbf{2 1 3 5 . 5 4}$ & $\mathbf{2 6 5 4 . 8 5}$ & $\mathbf{2 4 . 3 2}$ \\
\hline Grain-for-Blue & Regulating gases & 20550.32 & 25399.44 & 23.60 \\
& Water conservation & 19239.73 & 39079.81 & 103.12 \\
& Soil conservation & 3300.42 & 0.00 & -100.00 \\
& Nutrient cycling & 2400.89 & 1051.63 & -56.20 \\
\hline
\end{tabular}

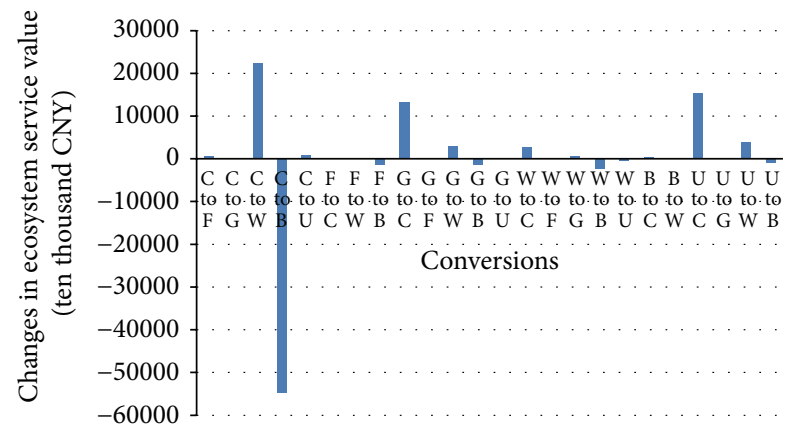

FIGURE 5: Changes in ESV due to land use conversions. Notes: C, F, G, W, B, and U are cultivated land, forestry area, grassland, water area, built-up area, and unused land, respectively; C to F means the conversion from cultivated land to forestry, and similarly for the others.

improved the ecosystem service function of nutrient cycling, organic material provision, and regulating gases, it also decreased the ecosystem service function of water conservation. Grain-for-Blue increased the ecological service function of water conservation but led to a decrease in soil conservation (100\%) and the nutrient cycling function (56.20\%).

Ecosystems comprise several different ecosystem service functions. A single ecological restoration policy cannot improve all the ecosystem service functions. Thus, we argue that integral ecological restoration policy should be adopted in ecological restoration. For example, when implementing Grain-for-Green in sloping areas, a water conservation project, such as rainfall collection, should be adopted simultaneously. Rainfall collection can not only improve the irrigation condition of farmland but also improve the water conservation function. When implementing the Grain-forBlue policy, a soil conservation project (such as afforestation) should also be considered. Furthermore, close attention must be given to the suitability of the policy. For example, Grainfor-Green in plain areas is of no benefit to the overall improvement of the ecosystem service function and should be strictly limited to sloping areas.
Most of the maps (e.g., NPP, NDVI) utilized to assess the changes in ESV in this paper are $1 \mathrm{~km}$ grid maps. The resolution of these maps could be too low at the provincial scale. In addition, owing to a lack of suitable method and data, we did not assess the ESV of regulating waste which is one of the most important ecosystem services of water areas. Thus, the ESV of water areas assessed in this paper could be underestimated. For the same reason, we also did not assess the ESV of the culture function which could also generate some uncertainty in the results for ESV.

\section{Conflict of Interests}

The authors declare that there is no conflict of interests regarding the publication of this paper.

\section{Acknowledgments}

This work was supported by the National Natural Science Funds of China for Distinguished Young Scholars (Grant no. 71225005), the National Natural Science Foundation of China (Grant nos. 41071343 and 41171434), and the Key Project in the National Science \& Technology Pillar Program of China (no. 2013BAC03B00).

\section{References}

[1] W. V. Reid, H. A. Mooney, A. Cropper et al., Ecosystems and Human Well-Being: Synthesis, Millennium Ecosystem Assessment, Island Press, Washington, DC, USA, 2005.

[2] Y. H. Lü, B. J. Fu, X. M. Feng et al., "A policy-driven large scale ecological restoration: quantifying ecosystem services changes in the loess plateau of China," PLoS ONE, vol. 7, no. 2, Article ID e31782, 2012.

[3] M. Shi, G. Ma, and Y. Shi, "How much real cost has China paid for its economic growth?" Sustainability Science, vol. 6, no. 2, pp. 135-149, 2011.

[4] W. Song and B. C. Pijanowski, "The effects of China's cultivated land balance program on potential land productivity at a national scale," Applied Geography, vol. 46, pp. 158-170, 2013. 
[5] W. Song, "Decoupling cultivated land loss by construction occupation from economic growth in Beijing," Habitat International, vol. 43, pp. 198-205, 2014.

[6] X. Q. Jia, B. J. Fu, X. M. Feng, G. H. Hou, Y. Liu, and X. F. Wang, "The tradeoff and synergy between ecosystem services in the Grain-for-Green areas in Northern Shaanxi, China," Ecological Indicators, vol. 43, pp. 103-113, 2014.

[7] W. Song and M. L. Liu, "Assessment of decoupling between rural settlement area and rural population in China," Land Use Policy, vol. 39, pp. 331-341, 2014.

[8] R. A. Logsdon and I. Chaubey, "A quantitative approach to evaluating ecosystem services," Ecological Modelling, vol. 257, pp. 57-65, 2013.

[9] J. A. Foley, R. DeFries, G. P. Asner et al., "Global consequences of land use," Science, vol. 309, no. 5734, pp. 570-574, 2005.

[10] M. J. Metzger, M. D. A. Rounsevell, L. Acosta-Michlik, R. Leemans, and D. Schröter, "The vulnerability of ecosystem services to land use change," Agriculture, Ecosystems and Environment, vol. 114, no. 1, pp. 69-85, 2006.

[11] E. Nelson, H. Sander, P. Hawthorne et al., "Projecting global land-use change and its effect on ecosystem service provision and biodiversity with simple models," PLoS ONE, vol. 5, no. 12, Article ID e14327, 2010.

[12] W. J. Sutherland, T. Gardner, T. L. Bogich et al., "Solution scanning as a key policy tool: identifying management interventions to help maintain and enhance regulating ecosystem services," Ecology and Society, vol. 19, no. 2, article 3, 2014.

[13] C. Perrings, A. Duraiappah, A. Larigauderie, and H. Mooney, "The biodiversity and ecosystem services science-policy interface," Science, vol. 331, no. 6021, pp. 1139-1140, 2011.

[14] R. J. Kemkes, J. Farley, and C. J. Koliba, "Determining when payments are an effective policy approach to ecosystem service provision," Ecological Economics, vol. 69, no. 11, pp. 2069-2074, 2010.

[15] J. Börner, A. Mendoza, and S. A. Vosti, "Ecosystem services, agriculture, and rural poverty in the Eastern Brazilian Amazon: interrelationships and policy prescriptions," Ecological Economics, vol. 64, no. 2, pp. 356-373, 2007.

[16] B. J. Fu, M. Forsius, and J. Liu, "Ecosystem services: climate change and policy impacts editorial overview," Current Opinion in Environmental Sustainability, vol. 5, no. 1, pp. 1-3, 2013.

[17] P. J. Ferraro, K. Lawlor, K. L. Mullan, and S. K. Pattanayak, "Forest figures: ecosystem services valuation and policy evaluation in developing countries," Review of Environmental Economics and Policy, vol. 6, no. 1, pp. 20-44, 2012.

[18] P. Kumar, S. E. Esen, and M. Yashiro, "Linking ecosystem services to strategic environmental assessment in development policies," Environmental Impact Assessment Review, vol. 40, pp. 75-81, 2013.

[19] L. E. Barry, R. T. Yao, D. R. Harrison, U. H. Paragahawewa, and D. J. Pannell, "Enhancing ecosystem services through afforestation: how policy can help," Land Use Policy, vol. 39, pp. 135-145, 2014.

[20] A. Jordan and D. Russel, "Embedding the concept of ecosystem services? The utilisation of ecological knowledge in different policy venues," Environment and Planning C: Government and Policy, vol. 32, no. 2, pp. 192-207, 2014.

[21] F. J. Sijtsma, C. M. van der Heide, and A. van Hinsberg, "Beyond monetary measurement: how to evaluate projects and policies using the ecosystem services framework," Environmental Science \& Policy, vol. 32, pp. 14-25, 2013.
[22] J. Hauck, C. Görg, R. Varjopuro, O. Ratamäki, and K. Jax, "Benefits and limitations of the ecosystem services concept in environmental policy and decision making: some stakeholder perspectives," Environmental Science and Policy, vol. 25, pp. 1321, 2013.

[23] K. Helming, K. Diehl, D. Geneletti, and H. Wiggering, "Mainstreaming ecosystem services in European policy impact assessment," Environmental Impact Assessment Review, vol. 40, pp. 82-87, 2013.

[24] M. Brady, C. Sahrbacher, K. Kellermann, and K. Happe, "An agent-based approach to modeling impacts of agricultural policy on land use, biodiversity and ecosystem services," Landscape Ecology, vol. 27, no. 9, pp. 1363-1381, 2012.

[25] C. E. Bronner, A. M. Bartlett, S. L. Whiteway, D. C. Lambert, S. J. Bennett, and A. J. Rabideau, "An assessment of U.S. stream compensatory mitigation policy: necessary changes to protect ecosystem functions and services," Journal of the American Water Resources Association, vol. 49, no. 2, pp. 449-462, 2013.

[26] D. Geneletti, "Assessing the impact of alternative land-use zoning policies on future ecosystem services," Environmental Impact Assessment Review, vol. 40, pp. 25-35, 2013.

[27] R. D. Simpson, "Ecosystem services as substitute inputs: basic results and important implications for conservation policy," Ecological Economics, vol. 98, pp. 102-108, 2014.

[28] B. Zhao, U. Kreuter, B. Li, Z. Ma, J. Chen, and N. Nakagoshi, "An ecosystem service value assessment of land-use change on Chongming Island, China," Land Use Policy, vol. 21, no. 2, pp. 139-148, 2004.

[29] Z. Guo, X. Xiao, Y. Gan, and Y. Zheng, "Ecosystem functions, services and their values-a case study in Xingshan County of China," Ecological Economics, vol. 38, no. 1, pp. 141-154, 2001.

[30] R. Costanza, R. d'Arge, R. de Groot et al., "The value of the world's ecosystem services and natural capital (Reprinted from Nature, vol. 387, no. 6630, pp. 253-260, 1997)," Ecological Economics, vol. 25, no. 1, pp. 3-15, 1998.

[31] R. Costanza, R. D’Arge, R. De Groot et al., "The value of the world's ecosystem services and natural capital," Nature, vol. 387, no. 6630, pp. 253-260, 1997.

[32] C. M. Peters, A. H. Gentry, and R. O. Mendelsohn, "Valuation of an Amazonian rainforest," Nature, vol. 339, no. 6227, pp. 655656, 1989.

[33] D. Tobias and R. Mendelsohn, "Valuing ecotourism in a tropical rain-forest reserve," $A M B I O$, vol. 20, no. 2, pp. 91-93, 1991.

[34] K. Chopra, "The value of non-timber forest products: an estimation for tropical deciduous forests in India," Economic Botany, vol. 47, no. 3, pp. 251-257, 1993.

[35] K. N. Ninan and M. Inoue, "Valuing forest ecosystem services: what we know and what we don't," Ecological Economics, vol. 93, pp. 137-149, 2013.

[36] J. O. Kenter, T. Hyde, M. Christie, and I. Fazey, "The importance of deliberation in valuing ecosystem services in developing countries-Evidence from the Solomon Islands," Global Environmental Change, vol. 21, no. 2, pp. 505-521, 2011.

[37] S. Silvestri, L. Zaibet, M. Y. Said, and S. C. Kifugo, "Valuing ecosystem services for conservation and development purposes: a case study from Kenya," Environmental Science and Policy, vol. 31, pp. 23-33, 2013.

[38] M. L. Mann, R. K. Kaufmann, D. M. Bauer, S. Gopal, J. G. Baldwin, and M. Del Carmen Vera-Diaz, "Ecosystem service value and agricultural conversion in the Amazon: implications for policy intervention," Environmental and Resource Economics, vol. 53, no. 2, pp. 279-295, 2012. 
[39] R. L. Deal, B. Cochran, and G. LaRocco, "Bundling of ecosystem services to increase forestland value and enhance sustainable forest management," Forest Policy and Economics, vol. 17, pp. 6976, 2012.

[40] W. F. Hyde and K. R. Kanel, The Marginal Cost of Endangered Species Management, IUCN, Cambridge, UK, 1994.

[41] R. Kramer and M. Munasinghe, Valuing a Protected Tropical Forest: A Case Study in Madagascar, IUCN, Cambridge, UK, 1994.

[42] P. C. L. White, K. W. Gregory, P. J. Lindley, and G. Richards, "Economic values of threatened mammals in Britain: a case study of the otter Lutra lutra and the water vole Arvicola terrestris," Biological Conservation, vol. 82, no. 3, pp. 345-354, 1997.

[43] M. M. Gardiner, C. E. Burkman, and S. P. Prajzner, "The value of urban vacant land to support arthropod biodiversity and ecosystem services," Environmental Entomology, vol. 42, no. 6, pp. 1123-1136, 2013.

[44] C. White, C. Costello, B. E. Kendall, and C. J. Brown, "The value of coordinated management of interacting ecosystem services," Ecology Letters, vol. 15, no. 6, pp. 509-519, 2012.

[45] X. Z. Deng, J. K. Huang, E. Uchida, S. Rozelle, and J. Gibson, "Pressure cookers or pressure valves: do roads lead to deforestation in China?" Journal of Environmental Economics and Management, vol. 61, no. 1, pp. 79-94, 2011.

[46] J. Y. Liu, M. L. Liu, H. Q. Tian et al., "Spatial and temporal patterns of China's cropland during 1990-2000: an analysis based on Landsat TM data," Remote Sensing of Environment, vol. 98, no. 4, pp. 442-456, 2005.

[47] X. Deng, J. Huang, S. Rozelle, and E. Uchida, "Economic growth and the expansion of urban land in China," Urban Studies, vol. 47, no. 4, pp. 813-843, 2010.

[48] X. Deng, Q. Jiang, H. Su, and F. Wu, "Trace forest conversions in Northeast China with a 1-km area percentage data model," Journal of Applied Remote Sensing, vol. 4, no. 1, Article ID 041893, 2010.

[49] S. Su, D. Li, Y. Hu, R. Xiao, and Y. Zhang, "Spatially nonstationary response of ecosystem service value changes to urbanization in Shanghai, China," Ecological Indicators, vol. 45, pp. 332-339, 2014.

[50] W. Guo, Valuation of ecosystem services based on remote sensing and landscape pattern optimization in Beijing [Ph.D. thesis], Beijing Forestry University, Beijing, China, 2012.

[51] W. H. Wischmeier, "A soil erodibility nomograph for farm land and construction," Journal of Soil and Water Conservation, vol. 26, pp. 189-193, 1971.

[52] K. G. Renard, G. R. Foster, and G. A. Weesies, Predicting Soil Erosion by Water: A Guide to Conservation Planning with the Revised Universal Soil Loss Equation (RUSLE), Handbook no. 703, U.S. Department of Agriculture, Washington, DC, USA, 1997.

[53] D. C. Flanagan, G. R. Foster, W. H. Neibling, and J. P. Burt, "Simplified equations for filter strip design," Transactions of the American Society of Agricultural Engineers, vol. 32, no. 6, pp. 2001-2007, 1989.

[54] K. K. K. Kuok, D. Y. S. Mah, and P. C. Chiu, "Evaluation of C and $\mathrm{P}$ factors in universal soil loss equation on trapping sediment: case study of Santubong River," Journal of Water Resource and Protection, vol. 5, no. 12, pp. 1149-1154, 2013.

[55] K. G. Renard and G. R. Foster, "Soil conservation: principles of erosion by water," in Dryland Agriculture, H. E. Dregne and W.
O. Willis, Eds., pp. 155-176, American Society of Agronomy, Soil Science Society of America, Madison, Wis, USA, 1983.

[56] Z. Y. Ouyang, X. K. Wang, and H. Miao, "A primary study on Chinese terrestrial ecosystem services and their ecologicaleconomic values," Acta Ecological Sinica, vol. 19, pp. 607-613, 1999. 

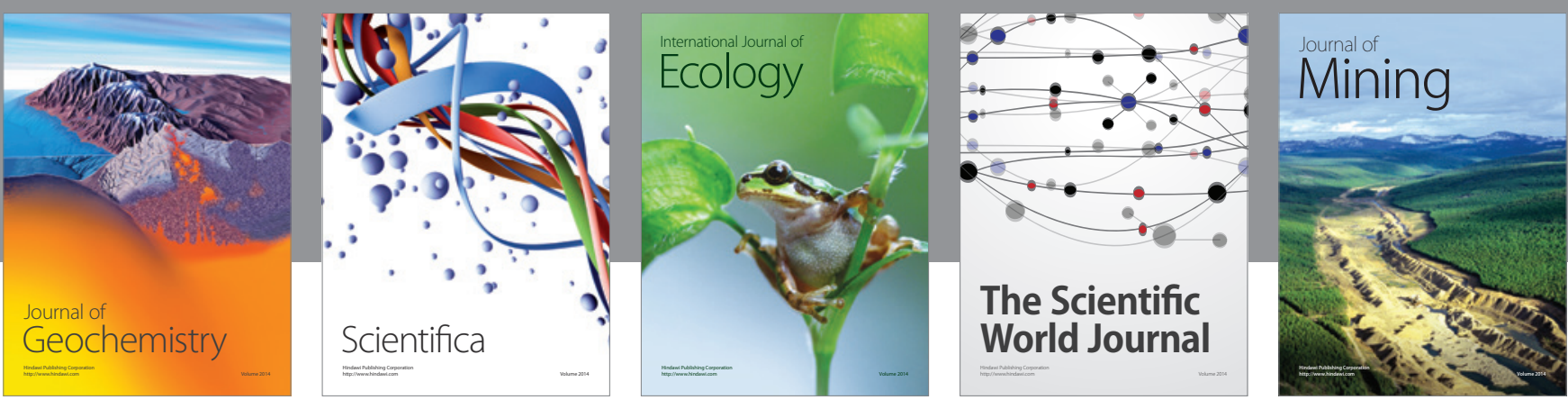

The Scientific World Journal
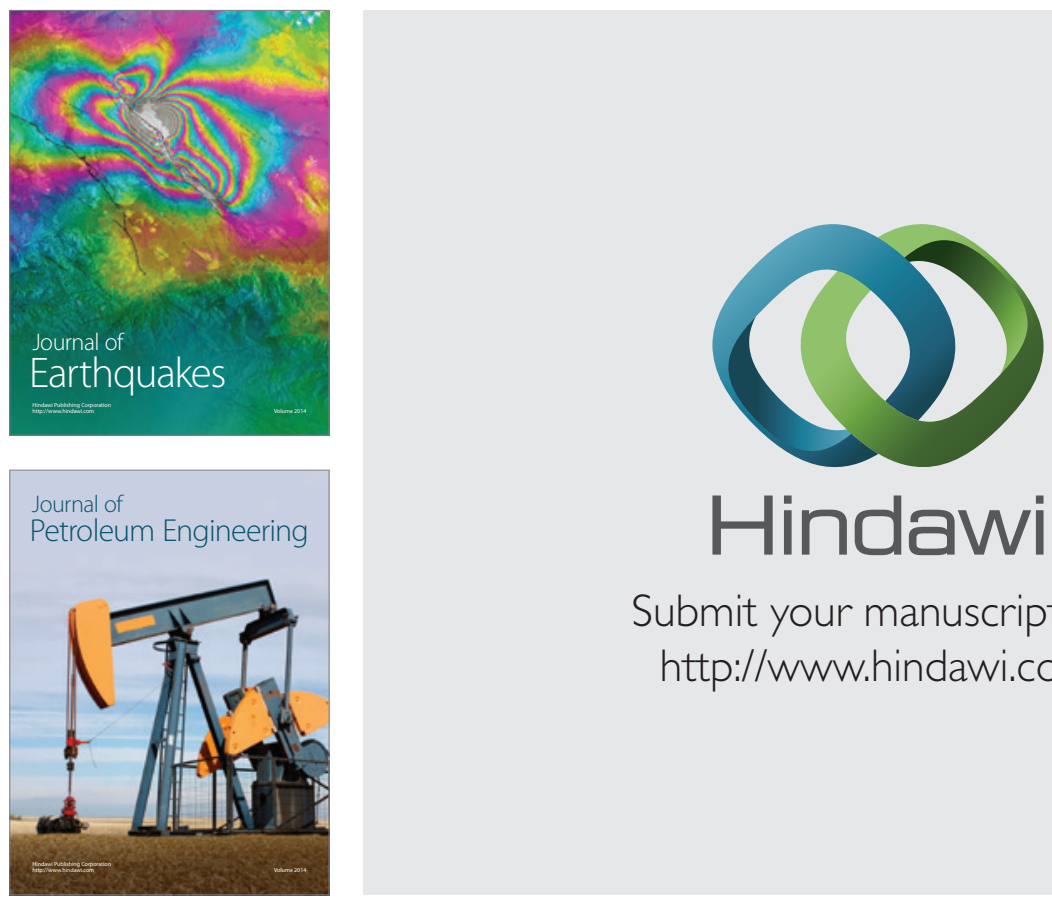

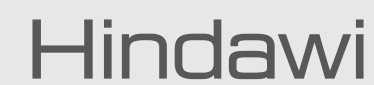

Submit your manuscripts at

http://www.hindawi.com
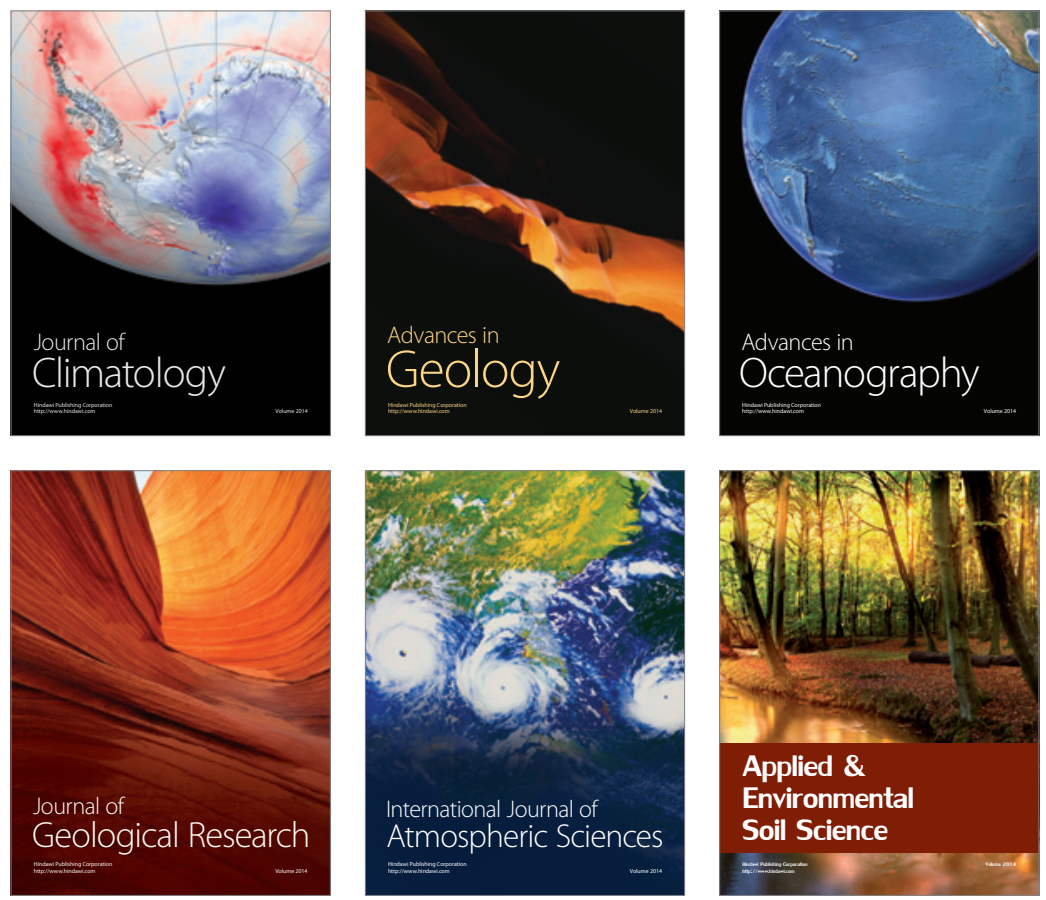
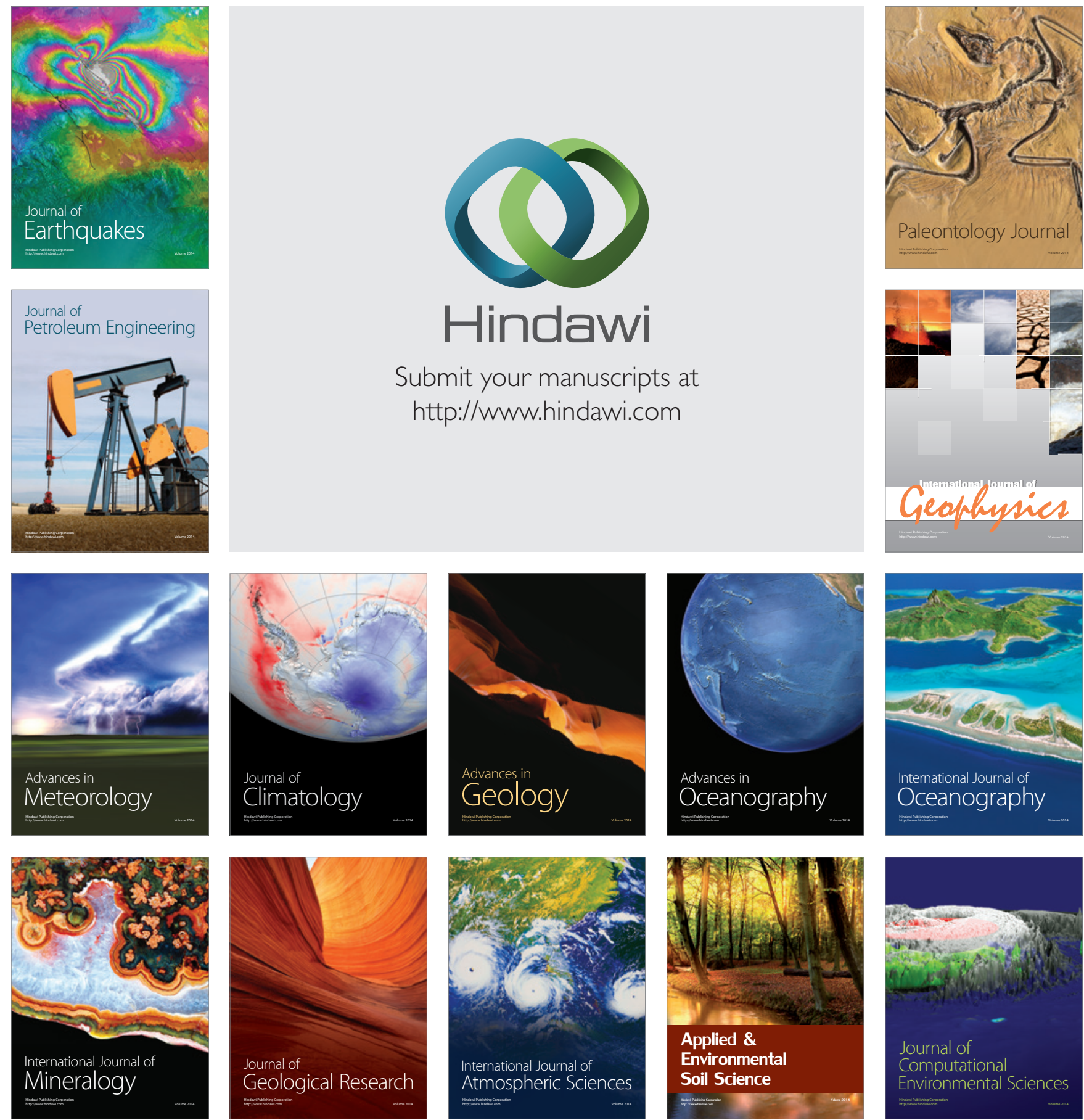